\title{
Socioeconomic Impacts of the Community-based Management of the Mangrove Reserve in Kerala, India
}

\author{
M. Hema ${ }^{\#}$ and P. Indira Devi \\ Dept. of Agricultural Economics, \\ College of Horticulture, Kerala Agricultural University, \\ Thrissur, Kerala, India - 680656 \\ \# Corresponding Author: \\ Tele: (91) 949521 1188; E-mail: hemamhari@gmail.com
}

\begin{abstract}
Kerala, once very rich in mangrove formations, perhaps next only to Sunder bans in the eastern part of the country, used to have a mangrove area extending to more than $700 \mathrm{~km}^{2}$ in 1987. The mangrove ecosystems are highly productive as agricultural land. Nevertheless the ecological significance of these was not appropriately accommodated amidst the development and demographic pressures and the decline in mangrove distribution and quality is reported to be disturbing. In this background the management options for mangrove conservation through societal participation was institutionalized though the policy decisions. The policy decision was taken to declare 150 hectares of ecologically sensitive mangrove system as community reserve through the notification in 2007. The programme aims to conserve the ecosystem through community participation while protecting their property and livelihood rights. This paper is drawn from an explorative look into the present dependence on the system, societal conflicts and responses to the proposed management plan. Based on the responses the study tries to suggest socially acceptable and ecologically just management option, for the ecosystem.

The direct stakeholders of mangrove system in the study area include both the residents as well as the non- residents in the locality. The direct benefits include the wood and non wood products as well as mussel farming, coir retting, fisheries and allied products. The life of these stakeholders depends heavily on various direct or indirect uses associated with the mangrove system. The study makes estimates of the value of these direct benefits through market based methods of valuation. The result of the study throws light on the existing status of mangroves in the area, reflect the social attitudes and responses to the policy, values the direct and indirect benefits of the system and suggest management options which are ecologically desirable and socially acceptable.
\end{abstract}

KEYWORDS: Community-based management, Mangroves, Direct valuation 


\section{Introduction}

Globally wetlands are considered as one of the most prolific and life supporting ecosystems. The significance and value of wetlands was first brought to the notice of the world through a Convention on Wetlands held at the Iranian city of Ramsar, in the year 1971. The Convention was an inter-governmental treaty that provided the framework for national action and international co-operation for the conservation and wise use of wetlands and their resources. The complex interaction between water, soils, topography, micro-organisms, plants and animals make wetlands the world's most productive ecosystems (Barbier et.al., 1997). Mangroves are multiple-use bio-diverse wetlands in the ecotone between sea and land. Mangrove forests are known by different names as coastal woodland, tidal forest, coastal bioshield (FAO, 2004). Mangroves are ' lungs of Earth' or ' lungs of coastal area' or 'coastal bio shield' - a diverse group of unrelated trees, shrubs, vines and ferns that share a common ability to live in water logged saline soils subjected to regular flooding. Mangroves are the rainforests by the sea.

The word "Mangrove" is a combination of two words, word "Mangue" the Portuguese and the English word "grove". Mangroves forests are seen in about one quarter of world's tropical coastline from $20^{\circ} \mathrm{N}$ to $20^{0} \mathrm{~S}$ latitudes (Walsh, 1974). Scientists are of the opinion that the earliest mangrove species originated in the Indo-Malayan region. This may account for the fact that there are far more mangrove species present in this region than anywhere else. Mangroves, the term is used to categorize trees and shrubs that have grown in and have developed morphological adaptations to the inter-tidal environment (e.g. aerial roots, salt excretion glands and vivipary of seeds) and to the ecosystem. Mangroves form a distinctive ecosystem composed of peculiar plants, animals and micro flora and fauna commonly found along sheltered coastlines, shallow-water lagoons, estuaries, rivers or deltas in the tropics and sub-tropics where they perform important socioeconomic and environmental functions. A vast majority of human population who live in coastal areas depend on local resources for their livelihood. The mangroves are sources of highly valued commercial products and fishery resources and also are sites for developing a burgeoning ecosystem. The mangrove forests provide wide range of materials for human sustenance ranging from fuel-wood collection to fisheries. The life of mangrove inhabited coastal areas depends on various goods and services provided by mangroves (Walton et al., 2007).

The functional importance makes mangrove ecosystem highly significant. The economic valuation has been considered as an endeavor to capture quantitative values of the goods and services provided by natural resources whose market prices are not directly ascertained. Total Economic Value (TEV) can be employed to capture the use and non use value of mangrove ecosystem (Barbier, 1994). The different goods and services provided by the mangrove ecosystem can be decomposed into use value and non-use value (Figure 1). The direct use values are fisheries, fodder, medicinal and similar uses and the indirect use values are 
expressed in terms of protection against high tides, coastal erosion, tsunami waves and similar natural catastrophes (Table 1). The non traded nature of the indirect values makes its valuation rather difficult or underestimated.

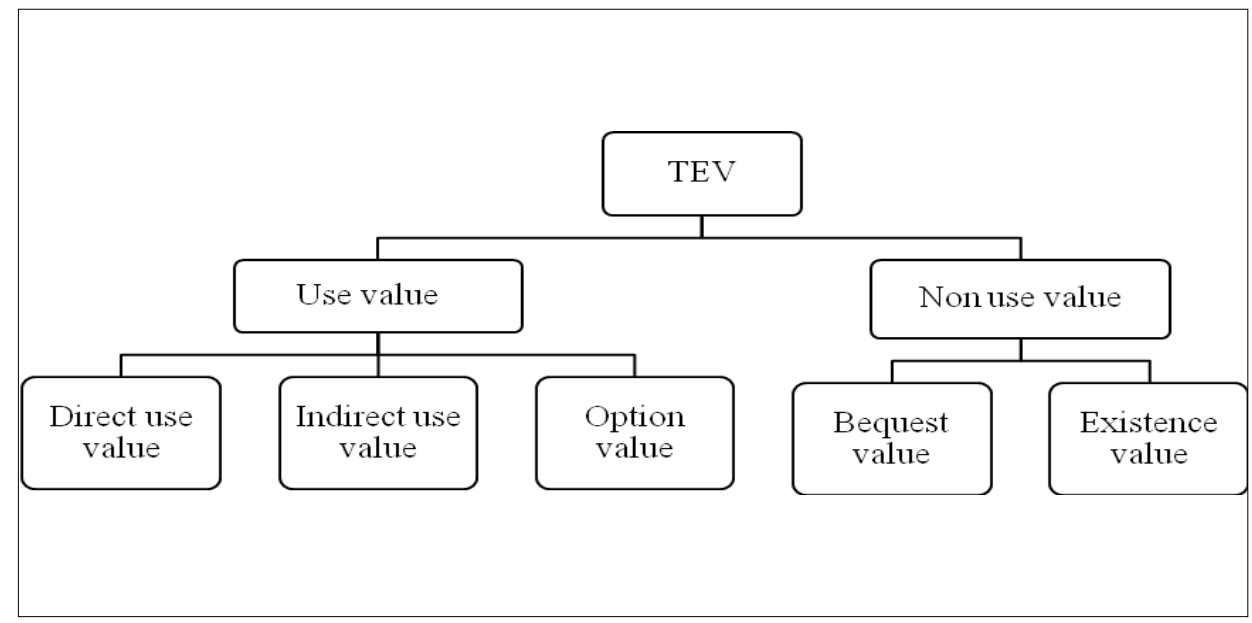

Figure 1: Classification of Total Economic Value (TEV)

Table 1: Classification of TEV of mangrove ecosystem

\begin{tabular}{|c|c|c|c|c|}
\hline \multicolumn{3}{|c|}{ Use Values } & \multicolumn{2}{|c|}{ Non-Use Values } \\
\hline $\begin{array}{c}\text { Indirect Use } \\
\text { Value }\end{array}$ & $\begin{array}{c}\text { Option } \\
\text { Value }\end{array}$ & $\begin{array}{c}\text { Indirect Use } \\
\text { Value }\end{array}$ & $\begin{array}{c}\text { Option } \\
\text { Value }\end{array}$ & $\begin{array}{l}\text { Indirect } \\
\text { Use Value }\end{array}$ \\
\hline Fuel wood & Nutrient sink & $\begin{array}{l}\text { Protection } \\
\text { against future } \\
\text { Tsunami waves }\end{array}$ & $\begin{array}{l}\text { Preserving } \\
\text { for future } \\
\text { generation }\end{array}$ & $\begin{array}{l}\text { Biodiversity } \\
\text { conservation }\end{array}$ \\
\hline Fodder & Flood control & $\begin{array}{l}\text { Protection } \\
\text { against future } \\
\text { Tsunami waves }\end{array}$ & & \\
\hline Medicine & $\begin{array}{l}\text { Breeding and } \\
\text { nursery ground } \\
\text { for fishes, } \\
\text { crustaceans }\end{array}$ & $\begin{array}{l}\text { Protection } \\
\text { against future } \\
\text { Tsunami waves }\end{array}$ & & \\
\hline Honey & $\begin{array}{l}\text { Shoreline } \\
\text { protection }\end{array}$ & $\begin{array}{l}\text { Protection } \\
\text { against future } \\
\text { Tsunami waves }\end{array}$ & & \\
\hline Tannins & Storm protection & $\begin{array}{l}\text { Protection } \\
\text { against future } \\
\text { Tsunami waves }\end{array}$ & & \\
\hline $\begin{array}{l}\text { Recreation \& } \\
\text { Aesthetic } \\
\text { Roofing and } \\
\text { Thatching } \\
\text { material }\end{array}$ & $\begin{array}{l}\text { Micro climate } \\
\text { stabilization } \\
\text { Water } \\
\text { purification }\end{array}$ & cyclones & & \\
\hline
\end{tabular}




\section{Background}

According to a comprehensive study by the Salim Ali Centre for Ornithology and Natural History, India lost about 38 per cent of its wetlands during the 1990s (Khaleel, 2009). The importance of mangroves has been underestimated and they are considered as highly critical and fragile ecosystems (Maguire et al., 2000). Mangrove ecosystems have extensive potential for offering a variety of direct and indirect uses and services to the living beings across the globe. Unfortunately, mangrove forests are now facing increased pressure and they have been cleared at an alarming rate for alternate purposes like urbanisation, agriculture, aquaculture etc. The life of mangrove inhabited coastal areas depends on mangrove trees for their household activities (Walton et al., 2007).

In recent years, population explosion and the desire for rapid economic growth have led to over- exploitation of mangrove ecosystem. From FAO (2004) report on the world fisheries, it was clear that around 35 percent of the world's mangroves had been lost already, of which majority of these areas fall in South Asian countries like India, Philippines and Vietnam. The major threats to mangrove forests and their habitats include clearing, exploiting, change in the river course, destruction of coral reefs, pollution, climate change etc. (Benton \& Twitchett, 2003; Dahdouh-Guebas et al., 2005; Zhang et al., 2007). The common property status and open access nature have led to the over exploitation and resource depletion of many natural resources.

Even though the institutional, social and legal interventions are there to conserve and restore these sensitive ecosystems, with the surge of urbanization in the last few decades, exploitation of mangrove forests has been intensified. Wetlands including mangroves are often considered as waste lands (Adger and Luttrell, 2000). Globalization and liberalization have resulted in the increased market integration and commercialization of the traditional economies. Until recently, mangrove forests have been classified by many governments as "wastelands" or useless swamps (Suma, 2000). The current revenue categorization of many wetlands as wasteland betrays the understanding of their importance and encourages their use as garbage dumps. This erroneous description has made it easier to exploit mangrove forests as cheap and unprotected sources of land for urbanization and other economic activities. (Radhakrishnan, et al., 2006)

In India, there are 38 mangrove areas under active implementation of the management action plans through the financial assistance of the Ministry of Environment and Forests (Government of India). Mangroves in India are spread over an area of $4639 \mathrm{~km}^{2}$ occupying only 0.14 percentage of the geographical area of the country with 3 percent of the global and 8 percent of Asian mangrove coverage (Kathiresan, 2010; SRF, 2009; FAO, 2007). In India, various regulatory measures like Forest Act 1927, Forest Conservation Act 1980, Coastal Regulation Zone (CRZ) notification, 1991and Environmental impact Assessment studies under EIA notification, 1994 (Kathiresan, 2010) are the prominent among them, to 
protect the vulnerable and fragile forest and coastal ecosystems. Mangroves are also covered under these measures.

Kerala with a coastline of about $590 \mathrm{~km}$ and 41 rivers emptying into the Arabian Sea, was once very rich in mangrove formations, perhaps second only to Sunder Bans in the eastern part of the country. There is a dearth in recent scientific data about the extent of the mangrove area in Kerala. Some reports estimate the area under mangrove cover as 70,000 hectares in 2004 (Mohanan, 2004). In 1991 Chand, 1991, reported it as $17 \mathrm{~km}^{2}$. Kerala has more than $900 \mathrm{~km}$ of interconnected waterways, rivers, lakes and inlets that together constitute the Kerala backwaters. The mangrove ecosystem of Kerala is nested within the backwater ecosystem. This interlinked network of waterways form an excellent matrix for the dispersal of mangrove propagules and the regulation of soil salinity: the two crucial factors determining mangrove presence and long term persistence in a landscape.

However the ecological importance of these were not properly taken care amidst the development and demographic pressures and the decline in mangrove distribution and quality is reported to be alarming. The high demographic pressure in Kerala also attributed to the rapid destruction of the mangrove ecosystems. The effect of urbanization at the cost of mangrove destruction is most evident in coastal areas of Kannur districts and Vypeen and Marad areas of Ernakulam. The conflicting interests of development (Theme Park in Kannur district and proposed Kerala Cricket Association (KCA) International Cricket stadium at Edakochi in Ernakulam district) Vs conservation is more pronounced in the recent past. Rapid urbanisation, conversion of mangrove area to coconut plantations, agriculture and ecotourism are the main drivers of mangrove loss in the state (Mohanan, 2004). In India, about 59 mangrove species are reported, of these, 14 species are seen in Kerala (Khaleel, 2009). Among the species seen in the state, nine species are common in the community reserve area (Table 2 ).

\section{Community-based Management}

The community based plans are proposed for the long term management of the natural ecosystems like mangrove ecosystems in selected areas with the active participation of all the stakeholders. The community based management is planned through community reserve programmes. The community reserve programme aims to conserve the ecosystem through community participation while protecting their property and livelihood rights. The basic approach of the community mangrove reserves is to conserve and manage the mangroves in the area with the active participation of the local people. Since the declaration of area under Coastal Zone Regulation -1(CRZ-1) there has been many conflicts between local people and the Government authorities. Community reserve is the area declared by the respective state Government in India for protecting flora, fauna, traditional or cultural heritage in the interests of a society (www. forest.kerala.gov.in). The Government of Kerala declared the Kadalundi-Vallikkunnu Reserve, on 2007 for conserving the 
biodiversity of the area with people's participation. The community reserve area includes Kadalundi Bird sanctuary and the mangroves.

Table 2: Common mangrove species in the study area

\begin{tabular}{|c|c|c|c|}
\hline SI No. & Scientific Name & Local Name & Local Uses \\
\hline 1 & Acanthus illicifolius & Chulli kandal & Fuel wood \\
\hline 2 & Avicennia officinalis & Upputty & $\begin{array}{l}\text { Filtering of salt from } \\
\text { saline water, Medicinal }\end{array}$ \\
\hline 3 & Excoecaria agallocha & Kannampotti & Medicinal \\
\hline 4 & $\begin{array}{l}\text { Rhizophora apiculata (Red } \\
\text { mangrove) }\end{array}$ & Valli kandal & Fuel wood \\
\hline 5 & $\begin{array}{l}\text { Rhizophora mucronata (Red } \\
\text { mangrove) }\end{array}$ & Branthan kandal & Fuel wood \\
\hline 6 & Sonneratia alba & Nakshatra kandal & Fodder \\
\hline 7 & $\begin{array}{l}\text { Avicennia merina (Black } \\
\text { mangrove) }\end{array}$ & Cheru upputty & $\begin{array}{l}\text { Filtering of salt from } \\
\text { saline water }\end{array}$ \\
\hline 8 & Bruguieraria cylindrica & Kutti kandal & Fodder \\
\hline 9 & Egiceras corniculatum & Poo kandal & Fuel wood \\
\hline
\end{tabular}

Source: Community Reserve Office, Kadalundi, Kozhikode. 2011

The estuarine area of the Kadalundi-Vallikkunnu are subjected to numerous biotic interferences like over fishing, collection of oysters and mussels, mining of sand and lime and also retting of coconut. The Government hence proposed the Community Reserve to protect the environmental situation of the area including flora and fauna. The working area Community Reserve is the area in VallikkunnuKadalundi villages in between Kottakkadavu bridge and Kadalundi river mouth and also Vallikkunnu and Kadalundi area up to 200 meters from the river borders. The aim of the community reserve is protection and development of all plants and animals including human beings in the community reserve area and also to conserve the bio-diversity of mangrove forest as well as to prevent the extinction of birds, fishes, other animals.

The project is managed by a Community Reserve Management Committee (CRMC) consisting of elected body of six members; of these five are elected from the general body of the community reserve area and the sixth member is an official from the forest department. The chairman is one among the elected members of the general body. The committee is empowered to prepare the management plan for the area, monitor and implement the same. For the smooth functioning of the CRMC, grass root level committees like Local Reserve Development Committees (LRDC) are there. The activities of the community reserve will be implemented through LRDC.

\section{Methodology}

In an attempt to understand the situation in the community managed mangroves ecosystem of Kerala- Kadalundi, the first declared mangrove community reserve in South India has been selected. A study was under taken in Kadalundi in 2011 
(Figure 2). Kadalundi is one of the fragile mangrove forests of Kerala, along the estuaries of Kadalundi and Vallikkunnu Panchayath of Kozhikode and Malappuram districts respectively. The area is an island and the ferry is the only mode of transport, apart from passenger bridges connecting different Thruths (small islands). Kadalundi is $18 \mathrm{~km}$ from South of Kozhikode city. The total areas of water lands and mangrove ecosystems in Kadalundi and Vallikkunnu Panchayath of Kozhikode are about 250 Hectares. Out of this, 150 hectares of ecologically sensitive mangrove system of Kadalundi Panchayat and Vallikkunnu Panchayat were declared as community reserve forest in 2007, which is perhaps the first of its kind in South India.

The objective of the study is to capture linkages between the conservation and management of the mangrove ecosystem in Kerala, India, in the background of the proposed Community Reserve Management Plan. The provisional livelihood services to the local community, property rights issues in the area and the conflicts that exist are being analyzed. The data had been collected from a random sample of 75 respondents out of 1600 families residing in the community reserve area. Data collection involved personnel interviews employing pre-structured questionnaires. To gather more information the management committee members of community reserve, the local public and general public in the nearby locality were also contacted.

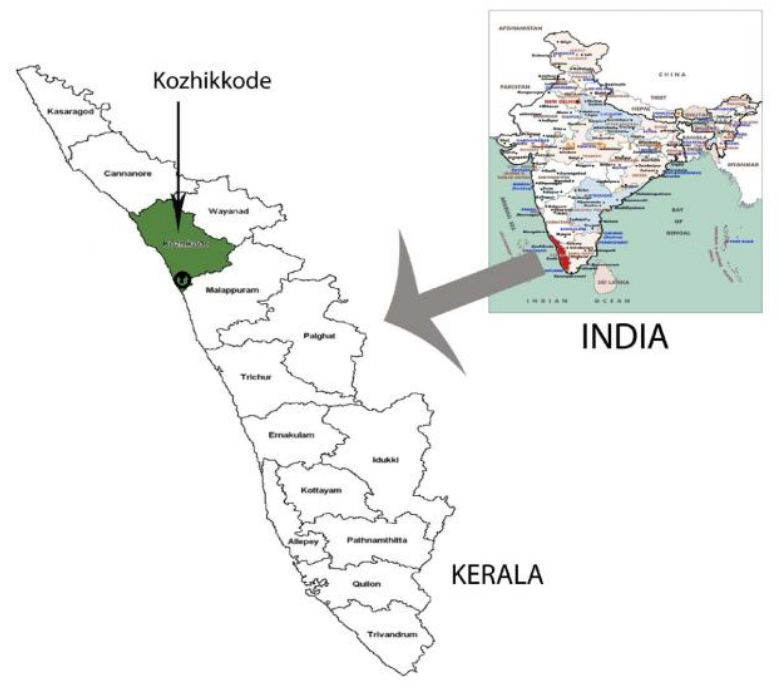

Figure 2: Study location in the geographical map of Kerala

\section{Results and Discussions}

\section{Demographic Data}

The summary statistics of the socioeconomic profile of the inhabitants are furnished in Table 3. The gender composition showed that 83 per cent of the respondents were 
males. Majority of the respondents in falls within the age group of $40-60$ years and followed by 23 percent of senior citizens. No considerable difference has been observed in the age pattern between the male and female groups. Contrary to the general pattern in Kerala, the education status happens to be very dismal, where the majority (42 percent) had only four years of formal schooling (Table 4).

Table 3: Distribution of sample by age and gender

\begin{tabular}{cccc}
\hline \multirow{2}{*}{ Age of Respondents } & \multicolumn{3}{c}{ Number and \% of Respondents } \\
\cline { 2 - 4 } & Male & Female & Total \\
\hline $20-40$ & $16(29 \%)$ & $15(75 \%)$ & $31(41.3 \%)$ \\
$40-60$ & $21(38 \%)$ & $3(15 \%)$ & $24(32 \%)$ \\
60 \& above & $18(33 \%)$ & $1(5 \%)$ & $19(25.3 \%)$ \\
\hline Total & $55(73.3 \%)$ & $20(26.6 \%)$ & $75(100 \%)$ \\
\hline
\end{tabular}

Table 4: Level of education of the sample group

\begin{tabular}{cccc}
\hline \multirow{2}{*}{ Years of Schooling } & \multicolumn{3}{c}{ Number and \% of Respondents } \\
\cline { 2 - 4 } & Male & Female & Total \\
\hline Less than 4 & $16(29 \%)$ & $15(75 \%)$ & $31(41.3 \%)$ \\
$4-7$ & $21(38 \%)$ & $3(15 \%)$ & $24(32 \%)$ \\
$8-12$ & $18(33 \%)$ & $1(5 \%)$ & $19(25.3 \%)$ \\
Above 12 & 0 & $1(5 \%)$ & $1(1.3 \%)$ \\
\hline Total & $55(73.3 \%)$ & $20(26.6 \%)$ & $75(100 \%)$ \\
\hline
\end{tabular}

This happens to be same with females, majority (three-fourth) with lower primary education. The total absence of graduates confirmed the observation made by Hussain and Badola (2010) in the study conducted in Orissa (India). The average land holding size was below $400 \mathrm{~m}^{2}$. Majority of households did not posses any boundary walls, and in certain circumstances mangrove succession into the compounds was observed. In Kadalundi area the total dependency of society on the mangrove system for their livelihood was very limited but they rely on various products from mangroves for their subsistence.

The asset position of the households reflect their financial status and it could be seen that most of houses were terraced or tiled and they posses durable consumer goods like, televisions, refrigerators etc. Mangroves form the boundary wall for majority of the households. The proliferation of the clams and other marine creatures like different fishes, prawns, crabs and other crustaceans after early nineties could be attributed to the conservation and expansion activities of mangrove like planting of some species like Rhizophora. The mudflats are rich in nutrients with fallen litters of the trees. The The various marine creatures migrate from the Arabian Sea to the mangrove area for food, breeds and regenerates to many folds, proving the positive relationship of mangroves and fisheries (Khaleel 
2009). The livelihood dependency and the physical assets of the people rely heavily on mangrove ecosystem either directly or indirectly. Mangroves had shielded the area from furious high tides and sea water intrusion during Tsunami, 2004. The shore line slides have been reduced substantially. Post monsoon salt water intrusion has been minimized due to the presence of mangroves.

\section{Economics of Mangrove Dependency of the Area}

Table 5 furnishes the details of occupational categorization of families. The aged or unemployed comprises the largest group, contributing very little to the family income and mostly depend on other members of the family for their livelihood and adding negligible share to family income. Similarly the house wives, either through dry fish production or mussel extraction contributes very little to the family income pool. Among the employed class, the largest group comprised of unskilled labourers (Coolies). The other sections of the employed groups include masons, toddy tappers, taxi drivers etc.

Table 5: Occupational categorization and monthly family income

\begin{tabular}{lccccc}
\hline $\begin{array}{c}\text { Main } \\
\text { Occupation }\end{array}$ & $\begin{array}{c}\text { \% of the } \\
\text { Total } \\
\text { Respondents }\end{array}$ & $\begin{array}{c}\text { Monthly } \\
\text { Income } \\
\text { (Other } \\
\text { Than } \\
\text { Mangroves) } \\
\text { (Rs.) }\end{array}$ & $\begin{array}{c}\text { Monthly } \\
\text { Household } \\
\text { Income } \\
\text { from } \\
\text { Mangroves } \\
\text { (Rs.) }\end{array}$ & $\begin{array}{c}\text { Total } \\
\text { Income }\end{array}$ & $\begin{array}{c}\text { \% of } \\
\text { Household } \\
\text { Income } \\
\text { from } \\
\text { Mangrove }\end{array}$ \\
\hline Coolie & 23 & 8750 & 3342 & 12092 & 38.2 \\
Fisherman & 20 & 0 & 15000 & 15000 & 100.0 \\
Mason & 8 & 11250 & 10700 & 21950 & 95.1 \\
Taxi Driver & 7 & 10000 & 0 & 10000 & 0.0 \\
Toddy Tappers & 4 & 7500 & 3200 & 10700 & 42.7 \\
Housewives & 9 & 0 & 1500 & 1500 & 100.0 \\
Aged/unemployed & 29 & 0 & 3990 & 3990 & 100.0 \\
\hline
\end{tabular}

Mangroves have been the sole source of income for the marginalized section, house wives. They were earning a small income of about Rs. 1500 per month. The masons happened to be the most affluent group compared to others, earning monthly an income of about Rs.21950, whereas fishermen, housewives and aged people, depended solely on mangroves for their livelihood. The nature of work restricts the taxi drivers' activities in mangrove area for any subsidiary income.

Even though the benefits or merits of mangroves have been known there were differences in judgment regarding its benefits among the respondents. The majority (79 percent of the respondents) (Table 6) believed storm protection as the important function of mangroves, followed by fisheries (68 per cent) and reduced soil erosion (63 per cent). Only very few respondents were ignorant about the importance of the mangroves and how it protect their life and property. On the contrary, mangroves 
were considered as problematic or troublesome owing to the presence of the large number of animals residing in the mangrove area.

Table 6: Analysis of the community perception towards mangroves

\begin{tabular}{lc}
\hline \multicolumn{1}{c}{ Description } & $\begin{array}{c}\text { Percentage of } \\
\text { Respondents }\end{array}$ \\
\hline Advantages & \\
No benefits & 4.0 \\
Fishing activity & 68.0 \\
Storm protection in tsunami & 78.7 \\
Prevent soil erosion & 62.7 \\
Prevent natural calamity & 33.3 \\
Breeding ground/nursery for fishes & 38.7 \\
Bird's resting place & 10.7 \\
No idea & 14.7 \\
\hline Disadvantages & \\
No drawbacks & 12.0 \\
Animals & 73.3 \\
Wastes & 33.3 \\
Mangroves are troublesome & 12.0 \\
\hline
\end{tabular}

The waste dumped into the Kadalundi River are normally accumulated in the mangrove areas and trapped in the root zone of the mangrove trees. Animals like stray dogs, foxes and even snakes are seen within the mangrove area and creating trouble to the communities residing on the coastal shores. The dogs and foxes are poaching the domestic fowls and kids of goats are reared in the households. The nuisance of the animals and waste accumulation can be considered as the important reasons for the negative attitude of people towards mangroves. Meanwhile the forest department officials had denied such confrontations in the absence of registered complaints.

All activities in the private mangrove holdings in CRZ II (Coastal Regulation Zone) including construction, land filling etc have been prohibited. But land owners are neither ready to hand over the land to the government against prevailing market price nor willing to conserve with financial assistance. The status quo maintenance happens to be the preferred option. Mangrove vegetation has been expanded into the Panchayat land, which was previously leased to local people for coconut cultivation. But as the mangroves areas were declared as ecologically sensitive areas, the panchayat has stopped leasing of land. This has affected the livelihood of local people and has led to a series of conflicts between the local people and the government departments. The local community is well aware about the ecological 
functions like shoreline protection and protection against strong winds performed by the mangroves but they are not willing to do any conservation measures for the protection of the same. The local community was interested to maintain the existing situation and not interested to do any conservation activities. Similarly the choice of conservation with active Government support was not an acceptable idea.

The local community has many apprehensions towards the idea of community reserve. They even fear that they might be evicted from their lands. The community reserve status does not prevent the ownership rights of the local people (private holdings) and the CRMC doesn't enjoy any such rights. With the reserve, there won't be any change in the land use pattern and it can be done only with the approval of the government (Anonymous, 2008). The political parties in the region are aggravating the issue with varied propaganda to gain mileage over the issue. Majority of the people in the community reserve are economically weak and are living in the fragmented lands.

The collection of fuel wood from the mangroves was the routine activity of the area and after the declaration of the community reserve; they are not allowed to collect any goods from the mangroves. The natural growth of regeneration of mangroves are very high and together with the absence of disturbance after the declaration of community reserve there has been luxuriant growth of the mangroves. Mangroves have even intruded into the house compounds and resulted anti feeling among the people towards mangroves. The community reserve management committee has organized different seminars, workshops, participatory rural appraisals and house visits to clarify the doubts of the local people and to build confidence in them about the activities of the community reserve.

\section{Economic Activities of the Area}

\section{Retting of Coconut Husk (Coir Retting)}

Till last decade, coir retting was the most lucrative income generating activity for the area. Nevertheless, it has been considered as the most extensive and damaging source of pollution affecting the entire backwater ecosystems of the region. Retting is mainly a soaking process where husks are arranged in bundles in huge coir nets (known as malis) and allowed to float freely in the backwaters, until they get soaked, then become heavy and gradually sink to the bottom. Bacteria, fungi and yeast are the main decomposers (Nandan, 2004). The process releases large amount of organic pollutants and depleted the benthic fauna in the water. So this decadesold process had been causing organic pollution in the near water bodies which slowly evoked strong protest among the local mass. Due to wide spread pollution in mid nineties local self government (village panchayat) of the area had imposed a complete ban of coir retting especially the immersing of coconut husk in the river shores. Since it was a livelihood stay for large number of local people the ban had affected the rural economy and its repercussions are still going on there. 


\section{Fisheries}

In the mangrove laden area the fisheries and allied activities occupies a prime importance. Major section of the local folks routinely engages in fishing activity either as their main occupation or subsidiary activity for one or two hours of the day. It was well reported by Snedaker and Snedaker (1984) that more than $90 \%$ of near shore marine species were found in the mangroves during one or more parts of their life cycles. A positive relationship between near shore fish stock and the extent of mangrove area has been well documented in Philippines, Indonesia, Malaysia and Australia (Macnae, 1974; Martosubroto and Naamin, 1977; Staples et al., 1985; Camacho and Bagarinao, 1986). The aged and non regular workers were also engaged in fishing at a subsistence level. Fishing as main occupation provides full day employment (about 8 hours per day) primarily for males. The males engaged in other occupations were also doing fishing as subsidiary activity for 1-2 hours per day. The females after their household activities devote 3-5 hours per day for allied fishing like mussel extraction and dry fish production (Table 7).

Table 7: Employment potential of fisheries

\begin{tabular}{ccccc}
\hline \multirow{2}{*}{$\begin{array}{c}\text { Employment } \\
\text { Creation }\end{array}$} & \multicolumn{2}{c}{$\begin{array}{c}\text { Working Hours } \\
\text { Per Day }\end{array}$} & \multicolumn{2}{c}{$\begin{array}{c}\text { Working Hours } \\
\text { Per Month }\end{array}$} \\
\cline { 2 - 5 } & Male & Female & Male & Female \\
\hline $\begin{array}{c}\text { Fishing (main } \\
\text { occupation) }\end{array}$ & 8 & & 200 & \\
\hline Subsidiary fishing & $1-2$ & $3-5$ & 50 & 5125 \\
\hline
\end{tabular}

\section{Mussel cultivation}

The Malabar region, extending from Malappuram to Kasargode districts of Northern Kerala, is a well-known mussel fishery zone of India. On an average 80 per cent of the total green mussel (Perna viridis) catch is exploited annually from this zone. The Malabar Coast is suitable for mussel farming during the post monsoon months (November to May) when high saline conditions prevails.

Large scale cultivation of green mussels is undertaken in the region. The local self government and Central Marine Fisheries Research Institute (CMFRI) Kochi have initiated few schemes for promoting the mussel cultivation. The local people have been engaged in mussel farming as primary or secondary occupation. They used to broadcast the mussel seeds on mud flats of river or in interconnected ropes on erected sticks in the water surface. A CMFRI technique of rope culture of the green mussel is adopted in the area, with floating rafts which are fabricated on teak pole and bamboo poles duly buoyed and anchored firmly are used for suspending culture ropes in the coastal seas at depth ranging from 5- $15 \mathrm{~m}$ (Harikumar and Rajendran, 2007). The technology of mussel farming is simple, economically viable and eco friendly. 
Apart from local masses, people from surrounding area have also been engaged in mussel cultivation as it is highly profitable. The seeds are generally procured from nearby areas. The harvestable stock will be produced in a period of 5 months to 8 months. A mean production rate of $10-12 \mathrm{~kg}$ can be obtained within $4-5$ months (Laxmilatha et al., 2009). The season normally starts from November- December to April- May. A standard 25 kilogram seed box produces twice or thrice its capacity fetches an average of Rs.1800 per box depending on the season. With increased adoption of mussel cultivation, demand for mussel seed increased substantially as a result of which trade in seed has developed into an allied mussel farming activity generating supplementary income to mussel pickers. The active mussel seed trade has taken place in nearby places such as Elathur, Kappad and Thikodi. About 100 kg seed costs Rs. 400- 500.

The mussel farming provides an excellent alternate livelihood option for the communities dependent on water bodies. Quite a small proportion of the local population has been engaged in a Tsunami Rehabilitation scheme which has undertaken rearing of Pearl spot under the name 'Theeramythri'.

\section{Dry Fish Production}

Dry fish production and extraction of Crassostrea madrasensis were generally carried out by the house wives after their regular household works. On an average this contributes a small fraction to their family income (Rs.1500 per month).

\section{Conclusions}

Few points for the conservation and management of mangroves of the area for the future generations are highlighted below:

- Complete ban on any construction activity in mangrove areas of both government and private holdings

- Strict enforcement of the Coastal Zone Regulation (CRZ-1)

- Proper awareness generation among the general public for the conservation and management of mangroves

- Restoration of degraded mangroves areas

- Preparation of scientific management plan incorporating scientists, politicians, respective department staffs, general public and other stakeholders.

Mangroves form an important component of the natural forest wealth of any nation. The study has clearly exposed the present status of the mangroves of the area. After the declaration of the community reserve in 2007 , the destruction of the mangroves has been reduced substantially. The rapid propagating nature of the mangroves resulted in the area expansion without any human intervention. The people in the 
community reserve have not been thoroughly convinced with the idea of community reserve. It has been attributed to the socio-political situation of the area. The concept of partnership with communities through community reserve as envisaged by the Government of Kerala may be materialized once the management plan of the community reserve has been finalized. The proposed management plan might nullify the fears of the local community towards community reserve.

Even though the government has initiated steps for acquiring the areas where mangroves have intruded into the household compounds the people are neither willing to accept nor willing to pay for the conservation of mangroves. It is a well established fact that the life and property of the people in these localities are preserved by these plants; they are not ready to take any measures for its conservation. People prefer to maintain the status quo. A constructive attitude has been slowly developing among the people through the series of seminars and interactions organized by the community reserve management committee The current problem of mangrove destruction would not be solved simply by declaring mangrove area as a protected area but only through the coordination and enforcement mechanisms of the government, community reserve management committee and the local people.

\section{References}

Adger, W. N. and C. Lutrell (2000). "Property Rights and the utilization of wetlands" Ecological Economics, 35: 75-89

Anonymous, (2008). "Sarovar Saurab" Salim Ali Centre for Ornithology and Natural History (SACON), 4(3) 8.

Barbier, E. B., M. Acreman and D. Knowler (1997). "Economic valuation of wetlands: A guide for policy makers and planners", Ramsar Convention Bureau.

Benton, M. J. and R. J. Twitchett (2003). "How to kill (almost) all life: The end-Premian extinction event" Trends Ecology Evoultion, 18: 358-365.

Camacho, A.S. and T. Bagarinao. (1986). "Impact of Fishpond Development on the Mangrove Ecosystem in the Philippines" In: Mangroves of Asia and the Pacific: Status and Management. Technical Report of the UNDP/UNESCO Research and Training pilot Programmed on Mangrove Ecosystems in Asia and Pacific.

Chand, B.S. (1991). "Distribution of mangroves in Kerala" Indian Forester, 117(6):439448.

Dahdouh-Guebas, F., Hettiarachchi, S., Lo Seen, D., Batelaan, O., Sooriyarachchi, S., Jayatissa, L. P., (2005). "Transitions in ancient inland freshwater resource management in Sri Lanka affect biota and human populations in and around coastal lagoons" Current Biology, 15(6), 579-586. 
FAO, (2007). “The world's mangroves 1980-2005" Forestry Paper No.153, Food and Agriculture Organization, Rome.

FAO. (2004). "The state of world fisheries and aquaculture" Food and Agriculture Organization (FAO), Rome.

Hardin, G. and J. Baden (1977). Managing the Commons, New York: W.H. Freeman.

Harikumar, G. and G. Rajendran (2007). "An overview of Kerala fisheries with- particular emphasis on aquacultutre of Kerala fisheries" IFP souvenir. Available from: http://ifpkochi.nic.in/IFPS2.pdf [Assessed 12 Jan. 2012].

Hussain, S. A. and R. Badola (2010). "Valuing mangrove benefits: contribution of mangrove forests to local livelihoods in Bhitarkanika Conservation Area, East Coast of India" Wetland Ecology Management, 18: 321-331.

Kathiresan, K. (2010). "Importance of mangrove forests of India" Journal of Coastal Environment, 1(1):11-26.

KFD [Kerala Forest Department] 2012. Available: http://forest.kerala.gov.in/index.php/ [Assessed 10 Jan.2012]

Khaleel, K. M. (2009). "Study of the ecosystem services and socio economic impact of mangrove wetlands of North Malabar" Research project. Kerala State Council for Science Technology and Environment (KSCSTE), 124.

Laxmilatha, P., S. Thomas, P. K. Asokan, V. G. Surendranathan, M. P. Sivadasan and N. P. Ramachandran (2009). "Mussel farming initiatives in north Kerala, India: a case of successful adoption of technology, leading to rural livelihood transformation" Sustainable aquaculture, XIV(4), 9-13.

Macnae, W. (1974). "Mangrove forest and fisheries" Food and Agriculture Organization, Rome IOFC:DEV.

Maguire, T., Saenger, P., Baverstock, P., and Henry, R. (2000). "Microsatellite analysis of genetic structure in the mangrove species Avicennia marina (Forsk.) Vierh. (Avicenniaceae)" Molecular Ecology, 9(11), 1853-62.

Martosubroto, P. and N. Naamin (1977). "Relationship between tidal forests (mangroves) and commercial shrimp production in Indonesia" Marine Research Indonesia, 18: 81-86.

Mohanan, C. (2004). "Conservation of the fragile ecosystem diversity of Kerala", Centre for Earth Science Studies, Internal Report, 381-398.

Nandan. B. S. (2004). "Studies on the Impact of retting on Aquatic Ecosystems" Limnological Association of Kerala, India

Snedaker, S.C. and J. G. Snedaker (1984). "The mangrove ecosystem: research methods" UNESCO, UK. 
Staples, D. J., Vance, D. J., Heales, D. S. (1985). "Habitat requirements of juvenile penaeid prawns and their relationship to offshore fisheries" In: Rothlisberg, P. C., Hill, B. J., Staples, D. J. (Eds.), Second Australian National Prawn Seminar, CSIRO, Cleveland, 47-54.

State Forest Report, (2009). Forest Survey of India, Dehradun.

Suma, K. P. (2000). "Physiological changes and distribution patterns of mangrove flora of Cochin” Ph.D Thesis, Mahatma Gandhi University, Kottayam.

Walsh, G. E. (1974). “Mangroves In: Ecology of halophytes” Academic press, New York.

Walton, M. E., Vay, L. L., Lebata, J. H., Binas, J., and Primavera, J. H. (2007). “Assessment of the effectiveness of mangrove rehabilitation using exploited and non-exploited indicator species" Biological Conservation, 138, 180-188.

Zhang, C. G., Leung, I. K. K., Wong, Y. S., and TAM, N. F. Y. (2007). "Germination, growth and physiological responses of mangrove plant (Bruguiera gymnorrhiza) to lubricating oil pollution" Environmental and Experimental Botany, 60, 127-136. 